\title{
KAJIAN TEORITIS LAYANAN KONSELING UNTUK KORBAN KEKERASAAN DALAM RUMAH TANGGA (KDRT)
}

\author{
Maria Oktasari ${ }^{1}$, Hayu Stevani ${ }^{2}$, Solihatun Solihatun ${ }^{3}$ \\ Dosen Bimbingan dan Konseling Universitas Indraprasta PGRI Jakarta \\ e-mail: oktasarimaria@gmail.com
}

\begin{abstract}
Domestic violence is an act against someone especially women which resulted in the incidence of misery or suffering physical, psychological, sexual and/or abandonment of the household including the threat to doing the deed, coercion or deprivation of freedom are against the law in the sphere of the household (UU No. 23 Th 2004). The incidence of suffering physical, psychological, and sexual abuse on victims of domestic violence will have an impact on the lives of either not effective daily. Therefore, the impact of which must be overcome. There are several ways to help cope with the impact of, the one with the granting of domestic violence counselling services to the victims. Granting counselling service aims to help overcome the problems experienced by victims of domestic violence. How the shape of the counselling services provided for victims of domestic violence will be discussed in this paper.
\end{abstract}

Keywords: Domestic Violence, Counseling Service

\begin{abstract}
Abstrak
Kekerasan dalam rumah tangga (KDRT) merupakan suatu perbuatan terhadap seseorang terutama perempuan yang mengakibatkan timbulnya kesengsaraan atau pendertiaan secara fisik, psikologis, seksual dan/atau penelantaran rumah tangga termasuk ancaman untuk melakukan perbuatan, pemaksaan atau perampasan kemerdekaan secara melawan hukum dalam lingkup rumah tangga (UU No.23 Th.2004). Timbulnya penderitaan secara fisik, psikologis, dan seksual pada korban KDRT akan berdampak tidak baik pada kehidupan efektif sehari-harinya. Oleh karena itu, dampak yang ditimbulkan tersebut harus diatasi. Ada beberapa cara untuk membantu mengatasi dampak tersebut, salah satunya dengan pemberian layanan konseling pada korban KDRT. Pemberian layanan konseling bertujuan untuk membantu mengatasi permasalahan yang dialami oleh korban KDRT. Bagaimana bentuk layanan konseling yang diberikan untuk korban KDRT akan dibahas dalam makalah ini.
\end{abstract}

Kata Kunci: KDRT, Layanan Konseling 


\section{Pendahuluan}

Fenomena kekerasan dalam rumah tangga (KDRT) dewasa ini merupakan bukan hal yang baru lagi, banyak kekerasan yang terjadi dalam lingkup rumah tangga tapi tidak banyak yang terungkap, bak fenomena gunung es yang nampak hanya puncaknya saja (Hartati, 2013). Artinya bahwa permasalahan kekerasan dalam rumah tangga yang terjadi selama ini, terlihat ke permukaan (publik) hanyalah sebagian kecilnya saja.

Permasalahan kekerasan dalam rumah tangga yang muncul juga lebih banyak dianggap sebagai sebuah permasalahan yang sifatnya pribadi dan seharusnya diselesaikan dalam lingkup rumah tangga saja (bersifat tertutup dan cenderung sengaja ditutup-tutupi) karena dianggap sebagai aib keluarga (Samudera, 2016). Padahal hal tersebut merupakan perilaku kejahatan/ tindakan kriminal. Seperti yang dijelaskan dalam Undang-undang (UU) tentang Penghapusan Kekerasan dalam Rumah Tangga (KDRT) No. 23 Tahun 2004 bahwa KDRT merupakan setiap perbuatan terhadap seseorang terutama perempuan, yang berakibat timbulnya kesengsaraan atau penderitaan secara fisik, seksual, psikologis dan/atau penelentaran rumah tangga termasuk ancaman untuk melakukan perbuatan, pemaksaan, atau perampasan kemerdekaan secara melawan hukum dalam lingkup rumah tangga (23, 2004). Secara tidak langsung UU tersebut menjelaskan bahwa KDRT merupakan pelanggaran hak asasi manusia dan kejahatan terhadap martabat kemanusiaan serta merupakan bentuk diskriminasi.

Banyaknya kasus kekerasan yang terjadi dapat dilihat dari data Komnas Perempuan. Pada tahun 2016 dari 16.217 kasus yang masuk dari lembaga layanan mitra Komnas Perempuan, kekerasan yang terjadi di ranah KDRT/RP tercatat $69 \%$ atau 11.207 kasus. Hal tersebut menunjukkan tingginya angka KDRT yang terjadi dikalangan masyarakat.

Hal tersebut tidak bisa biarkan begitu saja, karena kekerasan yang dilakukan oleh pelaku akan menimbulkan dampak negatif untuk korban. Seperti : Luka-luka fisik, rasa minder, takut, cemas dll. Cahaya Perempuan Women Crisis Center (2011) mengungkapkan bahwa ada beberapa dampak yang ditimbulkan, yaitu: 1) dampak fisik, 2) dampak psikis, 3) dampak seksual, 4) dampak sosial, dan 5) dampak ekonomi.

Dampak yang ditimbulkan tersebut harus diselesaikan, sehingga diperlukan berbagai cara untuk 
Maria Oktasari ${ }^{1}$, Hayu Stevani ${ }^{2}$, Solihatun Solihatun ${ }^{3}$

ISSN: 2615-3297 (Online) \& 2548-6500 (Print) menyelesaikannya. Salah satunya adalah memberikan layanan konseling untuk korban KDRT. Penjelasan mengenai layanan konseling untuk korban KDRT akan diuraikan lebih lanjut dibawah ini.

\section{Pembahasan}

\section{a. Kekerasaan dalam Rumah Tanggga (KDRT) \\ 1) Pengertian KDRT}

Kekerasan Dalam Rumah Tangga (KDRT) dapat diartikan sebagai tindakan kekerasan yang dilakukan oleh seorang pengasuh, orangtua, atau pasangan. KDRT dapat ditunjukkan dalam berbagai bentuk, di antaranya: Kekerasan fisik, penggunaan kekuatan fisik; kekerasan seksual, setiap aktivitas seksual yang dipaksakan; kekerasan emosional, tindakan yang mencakup ancaman, kritik dan menjatuhkan yang terjadi terus menerus; dan mengendalikan untuk memperoleh uang dan menggunakannya (Wahab, 2010).

Selanjutnya, Berdasarkan Undang-Undang No 23 tahun 2004 tentang PKDRT pada pasal 1 butir 1 menyebutkan bahwa Kekerasan dalam Rumah Tangga adalah setiap perbuatan terhadap seseorang terutama perempuan,

yang berakibat timbulnya kesengsaraan atau penderitaan secara fisik, seksual, psikologis, dan/atau penelantaran rumah tangga termasuk ancaman untuk melakukan perbuatan, pemaksaan, atau perampasan kemerdekaan secara melawan hukum dalam lingkup rumah tangga.

Berdasarkan penjelasan di atas, maka KDRT dapat diartikan suatu perbuatan terhadap seseorang yang menimbulkan kesengsaraan atau penderitaan secara fisik, seksual, psikologis dan atau penelantaraan rumah tangga yang dilakukan oleh orang-orang yang berada dalam lingkup rumah tangga.

2) Penyebab terjadinya KDRT

KDRT terjadi disebabkan oleh beberapa faktor, antaralain (Jayanthi, 2009):

a) Perselingkuhan

Perselingkuhan yang dimaksud adalah pengkhianatan yang dilakukan oleh suami dengan perempuan lain ataupun suami menikah lagi.

b) Masalah ekonomi

Laki-laki (suami) sebagai kepala keluarga tidak merasa bertanggungjawab dalam memberikan nafkah keluarga. 
Maria Oktasari ${ }^{1}$, Hayu Stevani ${ }^{2}$, Solihatun Solihatun ${ }^{3}$

ISSN: 2615-3297 (Online) \& 2548-6500 (Print)

Dengan kata lain, suami tidak memberikan nafkah kepada keluarga.

c) Budaya patriaki

Budaya patriaki merupakan sistem yang menempatkan ayah sebagai penguasa, sehingga dalam masyakarat istilah ini diartikan bahwa laki-laki berkuasa atas perempuan. Dengan kata lain, lakilaki mendapatkan tempat utama dalam kehidupan.

d) Campur tangan pihak ketiga

Campur tangan pihak ketiga yang dimaksud adalah adanya campur tangan dari pihak keluarga suami ] sehingga istri tidak merasa nyaman.

e) Bermain judi

Bemain judi merupakan sesuatu yang dilarang. Namun, bermain judi dapat memberikan kesenangan sehingga lupa akan segalanya termasuk keluarga.

f) Perbedaan prinsip

Prinsip menurut Kamus Besar Bahasa Indonesia merupakan asas (kebenaran yang menjadi pokok dasar berpikir, bertindak, dan sebagainya) ataupun dasar. Seseorang yang telah memiliki dasar dalam berperilaku maka akan selalu berpegang pada prinsip yang diyakininya. Apabila ada

orang lain yang mencoba untuk menggoyahkan prinsip tersebut maka seseorang akan tersinggung dan tidak terima. Dengan kata lain, hal tersebut dapat menjadi pemicu terjadinya KDRT.

\section{b. Layanan konseling untuk Korban KDRT}

Upaya penanganan tindak kekerasan pada korban KDRT diberikan melalui beberapa bantuan guna penyelesaian kasus tersebut seperti: 1) memberikan bantuan konseling dengan bekerjasama dengan Psikolog, 2) bekerjasama dalam hal penanganan medis, 3) pendampingan dan bantuan hukum, serta 4) rumah aman yang bentuknya kemitraan (Hartati, 2013). Dari beberapa upaya tersebut, makalah ini fokus akan membahas layanan konseling bagi korban KDRT.

Layanan konseling untuk korban KDRT merupakan bantuan yang diberikan kepada korban KDRT untuk membantu menyelesaikan permasalahan yang dihadapi korban sehingga korban mampu menjalani kehidupan efektif sehari-harinya. Seperti yang dijelaskan Cahaya Perempuan Women Crisis Center (2011) layanan konseling untuk korban 
Maria Oktasari ${ }^{1}$, Hayu Stevani ${ }^{2}$, Solihatun Solihatun ${ }^{3}$

ISSN: 2615-3297 (Online) \& 2548-6500 (Print)

KDRT merupakan kegiatan

mendengarkan dan membantu

korban KDRT agar dapat menghadapi masalahnya dan dapat menyatakan pilihan-pilihan untuk menanggulangi masalah tersebut.

Mengapa perlu diberikan layanan konseling? karena kekerasan dalam rumah tangga yang dilakukan pelaku KDRT akan menimbulkan dampak terhadap korban KDRT, baik dampak dalam jangka pendek atau langsung dan jangka panjang, seperti: dampak fisik, dampak psikologis, dampak seksual, dampak ekonomi dan dampak sosial (Sutrisminah, 2018).

Adanya dampak-dampak yang timbul akibat tindakan kekerasan dalam rumah tangga (KDRT) membuat kehidupan efektif korban KDRT menjadi terganggu, seperti : Korban menjadi tidak percaya diri (menutup diri), korban mengalami ketakutan yang berlebihan, hilangnya pekerjaan, kehamilan yang tidak diinginkan. Adanya dampak yang ditimbulkan tersebut, maka perlu diberikan layanan konseling.

Pelaksanaan layanan

konseling pada korban KDRT

berfokus pada permasalahan

bagaimana kejadian kekerasaan terjadi, bukan pada siapa yang melakukan kekerasan. Bentuk layanan konseling yang diberikan dikenal dengan istilah konseling feminis.

Konseling feminis sering disebut sebagai feminist counseling, counseling for women, sedangkan dalam dimensi klinis sering disebut sebagai feminist psychotherapies dan feminist therapy tetapi sering dipakai secara bersama-sama yaitu feminist counseling and therapy atau feminist counseling and psychotherapies (Enns, 1997).

Mengapa konseling feminis? Karena secara faktual, kebanyakan korban KDRT adalah perempuan. Seperti yang dijelaskan sebelumnya di penyebab terjadinya KDRT, yang salah satunya adalah budaya patriaki. Hal tersebut memposisikan bahwa perempuan itu adalah mahluk yang lemah dan pihak paling rentan terhadap kekerasan dalam rumah tangga maupun dalam relasi personal (Sinclair, 1999).

Adapun beberapa teknik dan strategi konseling feminis yang dikembangkan adalah sebagai berikut: 
1) Pemberdayaan.

Kekuatan konseling feminis adalah memberdayakan klien. Konselor membantu klien agar dapat menjadi pribadi yang mandiri dan mempunyai partisipasi yang seimbang dalam masyarakat.

2) Keterbukaan.

Hubungan antara konselor dengan klien dibangun melalui keterbukaan. Keterbukaan tidak hanya sharing informasi dan pengalaman tetapi ada hubungan timbal balik antara konselor dengan klien.

3) Menganalisis peran gender.

Konselor mengeksplorasi harapan-harapan klien yang berkaitan dengan peran gender dan dampaknya pada pengambilan keputusan untuk masa yang akan datang.

4) Intervensi peran gender.

Konselor memberikan pemahaman yang menekankan pada perbedaan peran antara laki-laki dengan perempuan

5) Bibliotherapy

Konselor memakai sumbersumber seperti buku non fiksi, buku teks bimbingan \& konseling, autobiografi, video pendidikan \& pengetahuan sebagai bahan diskusi bersama klien.

6) Latihan untuk asertif.

Konselor membantu klien untuk bersikap asertif sehingga klien mempunyai kesadaran tentang hak-haknya. Membantu mengubah stereotype negatif peran gender, mengubah keyakinan yang negatif dan mengimplementasikan perubahannya dalam kehidupan.

7) Reframing dan relabeling.

Konselor membantu klien untuk memahami akar permasalahan karena problem yang dialami klien berhubungan dengan tekanan sosial (social pressure) bukan semata-mata berasal dari dirinya.

8) Group work.

Pada akhir sesi konseling individual, konselor memberikan kesempatan klien untuk bergabung dalam kelompok. Langkah ini dimaksudkan agar klien merasa tidak sendiri dan dapat mendiskusikan pengalaman hidupnya.

9) Social action. 
Maria Oktasari ${ }^{1}$, Hayu Stevani ${ }^{2}$, Solihatun Solihatun ${ }^{3}$

ISSN: 2615-3297 (Online) \& 2548-6500 (Print)

Konselor mendorong klien

untuk terlibat dalam kegiatan

pemberdayaan perempuan,

menuliskan pengalaman

hidupnya atau aktif dalam

komunitas pendidikan yang

berlatar isu gender (Corey, 2015).

Selanjutnya ada tiga hal pokok dalam konseling feminis (Sanyata, 2010), yaitu:

1) Hubungan yang setara

Konseling dipandang
sebagai proses kerjasama,
dimana setiap individu dihargai
dalam kapasitas kekuatan yang
sama untuk mendiskusikan
pokok masalah dan strategi
pemecahan masalahnya (Toni
Sands dalam Sanyata, 2010).
Personal memiliki posisi politis
dalam masyarakat



perbedaan status, dan monokultural).

3) Konsep Nilai Berperspektif Perempuan (Valuing the female perspective)

Konselor dituntut untuk memiliki perspektif nilai dari sudut pandang klien, karena merupakan representasi dari keyakinan konselor bahwa mereka harus mempelajari karakteristik perempuan dalam membangun pandangan tentang dunia perempuan (femalecentered

views). Valuing the female perspective, sebagai upaya konselor untuk memahami dan memfasilitasi konseli dalam mengekspresikan perasaannya sesuai dengan nilai yang diyakininya.

Penjelasan di atas dapat disimpulkan bahwa layanan konseling feminis diberikan dengan tujuan untuk memberdayakan korban KDRT sehingga mampu untuk survive dan dapat menyelesaikan permasalahan yang dihadapi.

\section{Penutup}

Isu KDRT merupakan isu global yang dewasa ini merupakan 
Maria Oktasari ${ }^{1}$, Hayu Stevani ${ }^{2}$, Solihatun Solihatun ${ }^{3}$

ISSN: 2615-3297 (Online) \& 2548-6500 (Print)

bukan sesuatu yang baru lagi.

Layanan konseling yang

Fenomena kekerasan yang terjadi diberikan kepada korban KDRT dalam lingkup rumah tangga seperti fenomena gunung es yang nampak hanya puncaknya saja.

Ada banyak hal yang menyebabkan terjadinya KDRT, antaralain: 1) perselingkuhan, 2) masalah ekonomi, 3) budaya patriaki, 4) campur tangan pihak ketiga, 5) bermain judi dan 6) perbedaan prinsip. Terjadinya kekerasan yang dipicu oleh berbagai sebab di atas menimbulkan dampak bagi korban KDRT, sehingga diperlukan upaya untuk membantu korban. Salah satunya adalah pemberian layanan konseling.

Layanan konseling yang dimaksud adalah layanan konseling feminis. Layanan konseling diberikan dengan beberapa teknik, yaitu: 1) pemberdayaan, 2) keterbukaan, 3) menganalisis peran gender, 4) intervensi peran gender, 5) bibliotherapy, 6) latihan untuk assertif, 7) reframing dan reliabing, 8) Group work, 9) Social action. Hal tersebut dilandasi dengan tiga hal pokok dalam konseling feminis, yaitu: 1) hubungan yang setara, 2) personal memiliki posisi politis dalam masyarakat dan 3) konsep nilai berspektif perempuan. bertujuan untuk membantu korban dalam menyelesaikan permasalahan yang dihadapinya.

Daftar Pustaka

23, U-U.N. (2004). Tentang penghapusan kekerasan dalam rumah tangga (PKDRT)Corey, G. (2015). Theory and practive of counseling and psychotherapy NelsonEducation.

Enns, C. Z. (1997). Ferminist theories and ferminist psychotherapies: Origins, themes, and variations. Harrington Park Press/The Haworth Press.

Hartati, M. (2013). Studi tentang upaya penanganan tindak kekerasan terhadap perempuan dan anak (Studi kasus pada pusat pelayanan terpadu pemberdayaan perempuan dan anak (P2TP2A) Provinsi Kalimantan Timur)). Ejournal Fisip Unmul, 1(3), 1094-1106.

Jayanthi, E. T. (2009). Faktor-Faktor Penyebab Terjadinya Kekerasan Dalam Rumah Tangga Pada Survivor yang Ditangani oleh Lembaga Sahabat Perempuan Magelang. DIMENSIA, 3(2). 
Maria Oktasari ${ }^{1}$, Hayu Stevani ${ }^{2}$, Solihatun Solihatun ${ }^{3}$

ISSN: 2615-3297 (Online) \& 2548-6500 (Print)

Samudera, T. (2016). Faktor-Faktor

Penyebab Terjadinya Kekerasan

Dalam Rumah Tangga Dan Upaya

Penyelesaiannya. Journal of Legal

and Policy Studies, 2(2).

Sanyata, S. (2010). Aplikasi Terapi

Feminis Pada Konseling Untuk

Perempuan Korban KDRT.

Yogyakarta: Jurnal Bimbingan Dan

Konseling, Hlm, 4.

Sinclair, D. (1999). Memberdayakan

Perempuan Korban Kekerasan Dalam

Rumah Tangga/Hubungan Intim.

Trans). Poerwandari, Kristi. Woman

Studies Program, Graduated Studies

Program, University of Indonesia,

Not Published.

Sutrisminah, E. (2018). Dampak

Kekerasan Pada Istri Dalam Rumah

Tangga Terhadap Kesehatan

Reproduksi. Majalah Ilmiah Sultan

Agung, 50(127), 23-34.

Wahab, R. (2010). Kekerasan dalam

Rumah Tangga: Perspektif Psikologis

dan Edukatif. Unisia, (61), 247-256. 
JURNAL PSIKODIDAKTIKA || VOL: 3, NO: 1 Juni 2018 | 21 